UDC 663.43

IRSTI 65.43 .31

\title{
EXTRACTION OF FRUIT AND BERRY RAW MATERIALS FOR THE PRODUCTION OF BEER FOR SPECIAL PURPOSE
}

\author{
A.K. KEKIBAYEVA ${ }^{1}$, A.A. KANTAY', G.I. BAYGAZIYEVA ${ }^{1}$ \\ ( ${ }^{1}$ «Almaty Technological University» JSC, Almaty, Kazakhstan, \\ ${ }^{2}$ Kazakh National Agrarian University, Almaty, Kazakhstan) \\ E-mail: anara_06061983@mail.ru
}

Currently, the expansion of the range of the brewing industry is possible due to the introduction of an unconventional type of plant raw materials in the technology, which will allow producing special -purpose drinks with certain quality indicators. The main objective of the study is to determine the concentration of the extractant that allows extracting the maximum number of target components, optimal extraction parameters, and to evaluate the effect of pretreatment with enzyme preparations on the properties of fruit and berry raw materials. Studies have shown that solutions with an alcohol concentration of $60 \%$ vol. allow to increase the yield of alcohol and water-soluble substances. However, in order to obtain dyes from fruit and berry raw materials, it is recommended to use an extractant with a strength of $75 \%$, which extracts anthocyanin compounds to a greater extent.

Key words: brewer industry, extraction, fruit and berry raw materials, anthocyanins, wateralcohol solutions.

\section{АРНАЙЫ МАҚСАТТАҒЫ СЫРА ӨНДІРУ ҮШІН ЖЕМІС-ЖИДЕК ШИКІЗАТЫН ЭКСТРАГИРЛЕУ}

\author{
A.К. КЕКИБАЕВА ${ }^{1}$, А.А. КАНТАЙ ${ }^{2}$, Г.И. БАЙГАЗИЕВА ${ }^{1}$ \\ ( 1 «Алматы технологиялық университеті» АҚ, Алматы, Қазақстан, \\ ${ }^{2}$ Қазақ ұлттық аграрлық университеті, Алматы, Қазақстан) \\ E-mail: anara_06061983@mail.ru
}

Қазіргі уақытта сыра қайнату өнеркәсібінің ассортиментін кеңейту үшін технологияzа өсімдік шикізатының дәстүрлі емес түрін енгізумен мүмкін болады, бұл белгілі бір сапа көрсеткіштері бар арнайы мақсаттаzы сусындарды өндіруге мүмкіндік береді. Зерттеудің негізгі міндеті компоненттердің ең көп санын, экстрагирлеудің оңтайлы параметрлерін алуга мүмкіндік беретін экстрагенттің концентрациясын анықтау, сондай-ақ ферментті препараттармен алдын ала өңдеудің жеміс-жидек шикізатының қасиеттеріне әсерін багалау болып табылады. Жүргізілген зерттеулер спирттің 60\% көл. концентрациясы бар ерітінділер сиирт және суда еритін заттардың шызуын арттыруга мүмкіндік беретінін көрсетті. Бірақ жеміс-эндек иикізатынан бояzыштарды алу мақсатында күштіліzі 75\% экстрагентті пайдалануды ұсынуга болады, ол көбінесе антоциан қосылыстарын шыгарады.

Негізгі сөздер: сыра қайнату саласы, экстрагирлеу, жеміс-жидек шикізаты, антоциандар, сулы-спирт ерітінділері.

\section{ЭКСТРАГИРОВАНИЕ ПЛОДОВО-ЯГОДНОГО СЫРЬЯ ДЛЯ ПРОИЗВОДСТВА ПИВА СПЕЦИАЛЬНОГО НАЗНАЧЕНИЯ}

$$
\text { А.К. КЕКИБАЕВА }{ }^{1}, \text { А.А. КАНТАЙ }{ }^{2}, \text { Г.И. БАЙГАЗИЕВА }{ }^{1}
$$

( ${ }^{1}$ АО «Алматинский технологический университет», Алматы, Казахстан,

${ }^{2}$ Казахский Национальный аграрный университет, Алматы, Казахстан) E-mail: anara_06061983@mail.ru 
В настоящее время расиирение ассортимента пивоваренной промышленности возможно за счет внедрения в технологию нетрадиционного вида растительного сырья, что позволит производить напитки специального назначения с определенными показателями качества. Основной задачей исследования является определение концентрации экстрагента, позволяющей извлечь максимальное количество целевых компонентов, оптимальных параметров экстрагирования, а также оценить влияние предварительной обработки ферментными препаратами на свойства плодово-ягодного сырья. Проведенные исследования показали, что растворы с концентрацией спирта 60\% об. позволяют увеличить выход спирто- и водорастворимых веществ. Однако с целью получения красителей из плодово-ягодного сырья можно рекомендовать использовать экстрагент крепостью 75\%, который в больией степени извлекает антоциановые соединения.

Ключевые слова: пивоваренная отрасль, экстрагировние, плодово-ягодное сырье, антоцианы, водно-спиртовые растворы.

\section{Introduction}

One of the most important tasks of the brewing industry is to improve the quality of beer to meet the needs of various groups of the population, creating a drink with new properties by attracting new types of raw materials. The current trend of expanding the range of brewing production is the production of special Beers using non-traditional plant raw materials in order to form new physical, chemical, organoleptic and physiological properties of products [1].

This goal in developing new types of special beer can be realized by using widely available sources of carbohydrates as additives, in particular, honey, products of processing of fruit and berry raw materials, as well as their combinations.

Despite the long history of using such additives for beer production, a number of theoretical and practical problems remain unresolved. First of all, special attention should be paid to the research and development of technological modes, based on the maximum use of traditional brewing processes, existing technological equipment, production experience and traditions, when creating a technology for special beer and low-alcohol beverages.

Due to the fact that the processing of fruit and berry raw materials is seasonal, it is most appropriate to use concentrated semi-finished products, in particular, extracts, for obtaining fruit drinks. The use of intensive methods for their production, the use of new types of equipment in combination with optimal modes will allow for relatively small material and capital costs to obtain extracts at specialized plants or directly at enterprises that produce drinks based on them [2].
Industrial production of fermented bases for special beer should be based on the use of stable quality raw materials that can be stored for a long time. One of the requirements for such raw materials is the ability to use it for the production of beverages without additional processing, to produce drinks based on it with different quality indicators.

For the production of special beer in Breweries, it is advisable to use concentrated semi-finished products of a high degree of readiness with stable indicators, with an optimal content of all components, including growth factors, including raw materials [3].

It is appropriate to use concentrated juices, extracts, or concentrates prepared according to the type of concentrates for soft drinks. It does not require additional equipment for processing fruit and berry raw materials, there is no need to have production facilities for its storage. The composition of semi-finished products should be fairly uniform. While using concentrated semifinished products, it is possible to easily change the range of drinks, for example, by obtaining a wort with different initial extractivity or from blended raw materials.

One of these types of concentrated semifinished products can be fruit and berry extracts, which are obtained from standard raw materials of any quality [4]. The high content of dry substances in the extracts allows them to be stored for a long time. Their technology is quite simple, but there are disadvantages of the existing technology: a high duration of the process, the risk of microbiological contamination of intermediate products, and significant costs for concentrating dilute solutions. In this regard, the main objective of this study is to improve the technology of fruit and berry extracts and assess their quality in terms of the possibility of 
using them as the main raw material for the production of fermented bases.

\section{Objects and research methods}

The objects of research were fruits and berries of Aronia and black ash cultivated in the South Kazakhstan region. Fresh and quick-frozen fruits and berries stored at a temperature of minus $18 \pm 1^{\circ} \mathrm{C}$ were studied.

Enzymatic treatment of the pulp with the pectolytic enzyme preparation Pectophoetidine with polygalacturonase activity of $284 \mathrm{u} / \mathrm{g}$ was performed in order to increase the yield of dry soluble substances.

The analysis of raw materials was carried out according to the main physical and chemical parameters. The content of dry substances in the raw material was determined by drying, extractivity-by infusing [5] the content of Sugars-by Bertrand and iodometrically; the content of organic acids was estimated by titrated acidity, vitamin Cby iodometric method, and bioflavonoids-by Leventhal method [6]. The content of anthocyanin substances in the extract was determined by comparing the color intensity of a standard solution of cobalt sulphate and the extract.

Experimental studies were conducted at the Almaty technological University at the Department of "Technology of bread products and processing industries".

\section{Results and their discussion}

The main objective of this stage of the study is to determine the concentration of the extractant, which allows extracting the maximum number of target components, optimal extraction parameters, and to evaluate the effect of pretreatment with enzyme preparations on the properties of raw materials.

The research was carried out on the example of the fruits of black-fruited mountain ash (Aronia) and black currant berries. Berries were frozen and stored at a temperature of minus $18{ }^{\circ} \mathrm{C}$ for no more than six months.

The content of soluble dry substances, ascorbic acid, phenolic substances with $\mathrm{P}$ vitamin activity (bioflavonoids), and organic acids was studied in frozen raw materials. Table 1 shows the results of studies of quality indicators of raw materials.

In the process of cold storage, the quality indicators of raw materials slightly changed: the dry matter content increased by $0.2-0.3 \%$ due to freezing. The concentration of vitamin $\mathrm{C}$ decreased in Aronia by 2.2...4.0; in currants, 3.0...4.5\%.

Thus, this method of storage can be considered sparing in terms of preserving the nutritional value of fruits and berries.

Table 1 - The quality indicators of frozen raw materials

\begin{tabular}{|c|c|c|}
\hline Main components & Aronia & Black currant berries \\
\hline \multicolumn{3}{|c|}{ Mass fraction: $\%$} \\
\hline dry material & $24-25$ & $16,3-17,4$ \\
\hline reducing Sugars (in terms of glucose) & $7,86-8,88$ & $8,26-8,83$ \\
\hline organic acids (in terms of malic acid), $\%$ & $0,82-1,1$ & $3,2-4,5$ \\
\hline vitamin $\mathrm{C}, \mathrm{mg} \%$ & $10,3-14$ & $167-203$ \\
\hline bioflavonoids (in terms of rutin), $\%$ & $2,9-3,3$ & $1,77-2,90$ \\
\hline
\end{tabular}

Attention is drawn to the high concentration of bioflavonoids in both Aronia and blackcurrant. Therefore, when determining the total amount of extracted soluble substances, it is necessary to take into account the degree of extraction and these important raw material components.

The strength of the water-alcohol extractant must be set depending on the nature and properties of the extracted substances. Therefore, we conducted studies of the effect of alcohol concentration on the yield of soluble substances from quick-frozen fruits of blackcurrant and blackcurrant berries, and also determined the duration of extraction to extract the maximum amount of dry substances in a stationary infusion.

The lower level of the strength of the wateralcohol solution of $40 \%$ was chosen from the conditions that the preserving effect during extraction is achieved by the content of 18 in the Morse...20\% ethyl alcohol. According to the literature, it is recommended to use solutions with a strength of 45 to $75 \%$ to obtain morsels from fresh raw materials, so the upper level of the strength of the water-alcohol solution is $80 \%$ [7].

Frozen raw materials were pre-crushed, not allowing complete thawing in order to avoid loss of dry matter. To increase the yield of dry soluble substances, the pulp was enzymatically 
treated with pectolytic enzyme preparation Pectofoetidine with polygalacturonase activity of 284 units / g. The dose of Pectofoetidine was $0.01 \%$ for chokeberry and $0.03 \%$, processing parameters - temperature $45^{\circ} \mathrm{C}$, duration 1 hour.

The treated pulp was divided into a series of samples and poured with water-alcohol solutions.

The ratio of the mass flow of raw materials and liquid selected 1:2. With a lower ratio, the surface of the pulp is not sufficiently coated with the solution, and with an increase in the consumption of extractant, the dilution of fruit drinks increases, which leads to an increase in energy costs for dealcoholization and concentration of fruit drinks.

Infusion was carried out once, in the resulting fruit drinks the concentration of solids and volume were determined.
The duration of extraction is more affected by the concentration of the extractant. The greatest degree of diffusion of dry soluble substances occurs in the range of alcohol concentrations from 55 to $75 \%$ vol. The maximum amount of dry matter $56.7 \%$ for blackcurrant and $66.3 \%$ for blackcurrant is extracted in 48 hours when using a solution with a strength of $60 \%$.

A control sample with a stationary infusion method was fruit juice obtained by extracting raw materials with water according to the technology described above. In the samples obtained by extraction with water and $60 \%$ ethanol, the main physicochemical parameters were determined. The results of studies of fruit drinks are presented in tables 2-3.

Table 2 - Physico-chemical characteristics of blackcurrant fruit drinks

\begin{tabular}{|l|c|c|}
\hline \multirow{2}{*}{ Physical and chemical indicators } & \multicolumn{2}{|c|}{ Type of fruit drink } \\
\cline { 2 - 3 } & alcoholized & water \\
\hline Mass fraction of soluble solids, \% & $5,4 \pm 0,3$ & $4,3 \pm 0,3$ \\
\hline Mass fraction of reducing sugars, \% & $4,80 \pm 0,02$ & $3,70+0,02$ \\
\hline Mass fraction of ethanol,\% & $38,2+1,2$ & - \\
\hline $\begin{array}{l}\text { Mass fraction of titratable acids (in } \\
\text { terms of malic acid), \% }\end{array}$ & $1,3 \pm 0,2$ & $0,8 \pm 0,2$ \\
\hline Active acidity, pH & $3,92 \pm 0,04$ & $3,40 \pm 0,04$ \\
\hline The content of vitamin C, $\mathrm{mg} \%$ & $87,4 \pm 3,5$ & $38,6 \pm 1,0$ \\
\hline The concentration of dyes, g / dm ${ }^{3}$ & $4,11 \pm 0,05$ & $3,69 \pm 0,05$ \\
\hline $\begin{array}{l}\text { Polyphenolic substances (in terms of } \\
\text { rutin), mg \% }\end{array}$ & $326 \pm 5$ & $310 \pm 5$ \\
\hline
\end{tabular}

Table 2 - Physico-chemical characteristics of chokeberry fruit drinks

\begin{tabular}{|l|c|c|}
\hline \multirow{2}{*}{ Physical and chemical indicators } & \multicolumn{2}{|c|}{ Type of fruit drink } \\
\cline { 2 - 3 } & alcoholized & water \\
\hline Mass fraction of soluble solids, $\%$ & $6,4 \pm 0,2$ & $6,1 \pm 0,2$ \\
\hline Mass fraction of reducing sugars, $\%$ & $6,12 \pm 0,02$ & $5,52 \pm 0,02$ \\
\hline Mass fraction of ethanol, $\%$ & $42,0 \pm 1,5$ & - \\
\hline $\begin{array}{l}\text { Mass fraction of titratable acids (in terms } \\
\text { of malic acid), } \%\end{array}$ & $0,66 \pm 0,1$ & 0,12 \\
\hline Active acidity, $\mathrm{pH}$ & $3,75 \pm 0,04$ & $3,60 \pm 0,04$ \\
\hline The content of vitamin C, $\mathrm{mg} \%$ & $5,27+1,05$ & $3,41+0,8$ \\
\hline The concentration of dyes, $\mathrm{g} / \mathrm{dm}^{3}$ & $4,66 \pm 0,05$ & $4,29 \pm 0,05$ \\
\hline $\begin{array}{l}\text { Polyphenolic substances (in terms of } \\
\text { rutin), mg } \%\end{array}$ & $378 \pm 5$ & $301 \pm 5$ \\
\hline
\end{tabular}

From tables 2-3, it follows that the resulting alcoholic drinks are characterized by a high content of reducing Sugars, polyphenolic, coloring substances, and organic acids. The content of vitamin $\mathrm{C}$ in water morsels is less by $35-45 \%$, probably due to oxidation with oxygen dissolved in water. There are also $8-15 \%$ fewer colorants in water morsels than in alcohol-based ones.

The berries of black currant and the fruits of Chokeberry are intense in color, due to the high content of natural plant pigments anthocyanins. Dyes are found mainly in the skin, as well as in dissolved form in cellular juice. 
Their content correlates with the total concentration of polyphenolic substances. The process of extracting dyes is of interest, since the obtained extracts can be used as a flavoring and coloring agent for drinks.

Extraction of coloring substances was carried out by infusing water-alcohol solutions, taking into account the best solubility of the main components of pigments in alcohol.

Frozen raw materials were crushed in the same way as in the previous series of experiments, in order to stabilize the anthocyanins, citric acid was added to it $0,2 \%$ by weight of the raw material. Then the resulting pulp was extracted with 96, 75, 60 and $40 \%$ water-alcohol solution in a ratio of $1: 2$ for 4,6 , 12 and 18 hours. the content of anthocyanins was determined by comparing the color intensity of the standard solution of cobalt sulphate and the extract. The dynamics of the yield of anthocyanins is shown in figure 1.

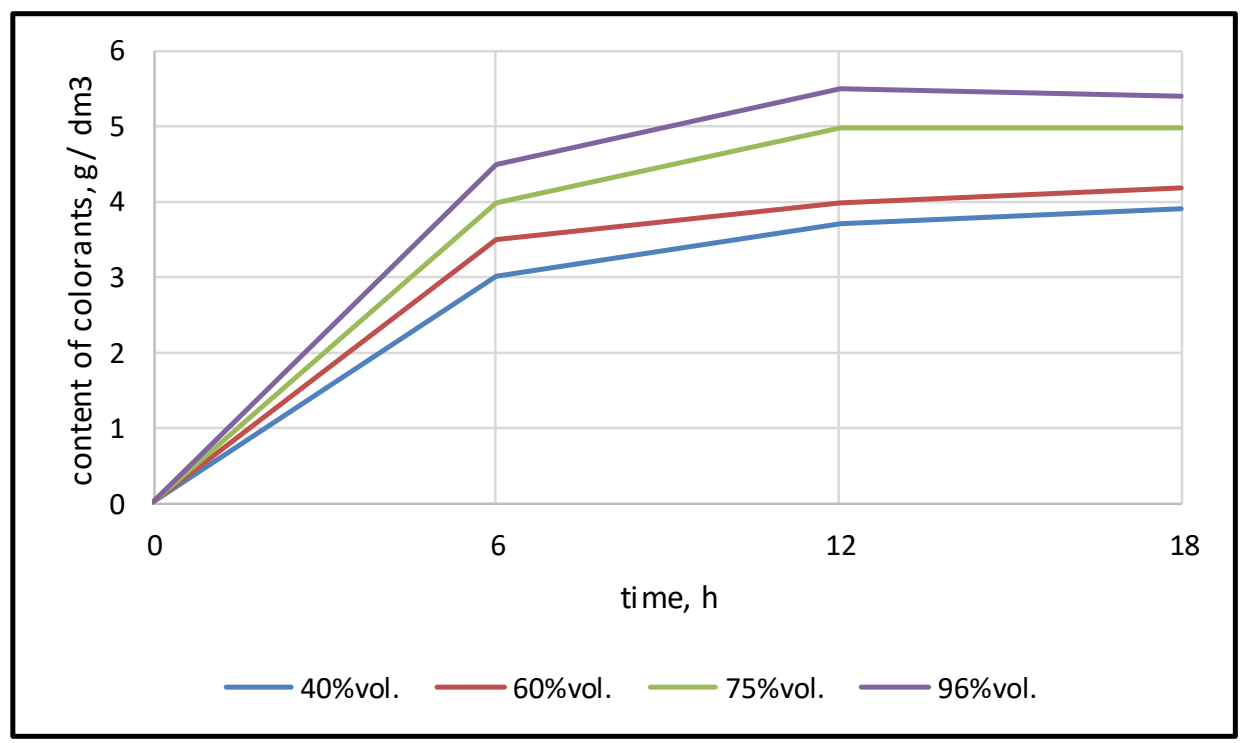

a)

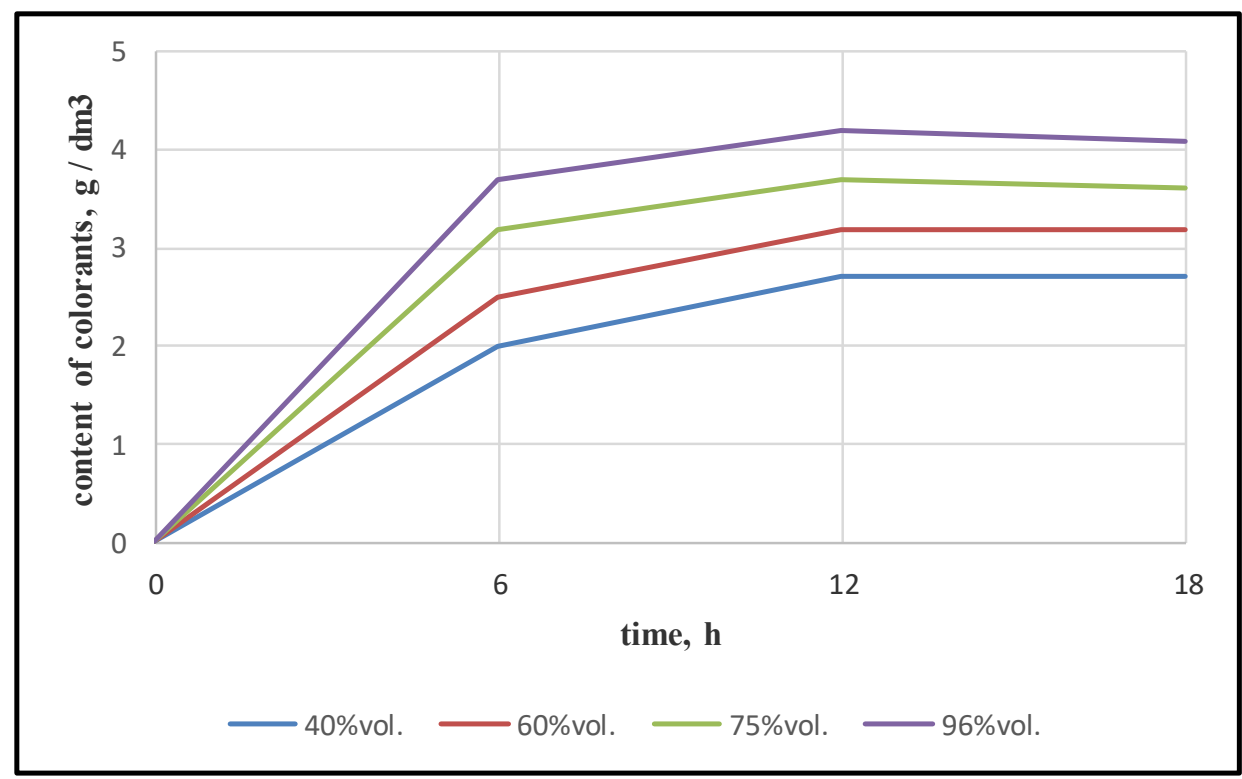

b)

Figure 1. Dynamics of the output of coloring substances depending on the concentration of the extractant: achokeberry; b-blackcurrant 
According to the results of the analyzes, it was found that the samples obtained by infusion with $96 \%$ and $75 \%$ alcohol solutions have a higher content of coloring substances: for blackcurrant $4.153 .8 \mathrm{~g} / \mathrm{dm}^{3}$ and $3.8 \mathrm{~g} / \mathrm{dm}^{3}$, aronia $-5.493 .8 \mathrm{~g}$ $/ \mathrm{dm}^{3}$ and $513.8 \mathrm{~g} / \mathrm{dm}^{3}$. The extracts have a stable dark red color, transparency, a pronounced aroma of blackcurrant or chokeberry, complete solubility in water-alcohol solutions.

\section{Conclusion}

Studies have shown that solutions with an alcohol concentration of $60 \%$ vol. they allow increasing the yield of alcohol and water-soluble substances. However, in order to obtain dyes from blackcurrant and blackcurrant, it is recommended to use an extractant with a strength of $75 \%$, which extracts anthocyanin compounds to a greater extent.

A feature of the process of extracting food raw materials is a significant change in its physical properties during the extraction process, which has a significant impact on all stages of the process.

\section{REFERENCES}

1. Voronina P. K., Kurochkin A. A. Formation of beer quality in the process of fermentation of beer wort using barley extrudate // Agronomy and plant protection. - 2012. №4- P. 42-44. [in Russian]

2. Pomozova V. A. Theoretical and practical aspects of developing the technology of special beer and low- alcohol beverages using fermented bases from natural carbohydrate -containing raw materials : dis. ...dr tekhn.sciences: 05.18.07 / Pomozova Valentina Alexandrovna.- Kemerovo, 2002.- 393p. [in Russian]

3. Faradzheva E. D. and others. Development of a beer-type beverage using non-traditional raw materials. - Beer and drinks, 2011. - №6.- P. 33-37. [in Russian]

4. Sorokopud A. F., Ivanov P. P. Fruit and berry extracts of Western Siberia: theoretical and practical aspects // Kemerovo technological Institute of food industry. - 2014. - P. 136. [in Russian]

5. Ermolaeva G. A. Handbook of the laboratory worker of the brewing company-St. Petersburg.: Publishing house of Profession, 2004 - P. 535. [in Russian]

6. Kunze W. Technology of brewing and malting.-translation from German. SPb., Profession publishing house, 2011. - 912 p. [in Russian]

7. Kiseleva T. F., Kuziv E. M., Pomozova V. A. Improving the technology of low-alcohol fermented beverages // Beer and beverages. - 2005. no. 2.- PP. 12-19. [in Russian]

УДК 637.18

МРНТИ 53.01 .91

\title{
БАДАМ СУТІНЕН БАЛМҰЗДАҚ ЖАСАУДЫН ЖАНА ТЕХНОЛОГИЯСЫ
}

\author{
Н.С. МАШАНОВА, М.Е. СМАГУЛОВА, С.Т. АЗИМОВА', Ж.И. САТАЕВА ${ }^{l}$
}

('С. Сейфуллин атындағы Қазақ агротехникалық университеті, Нұр-Сұлтан қаласы

2 «Алматы технологиялық университеті» АҚ, Алматы қ., Қазақстан)

E-mail: mirgul.smagulova@bk.ru

Мақалада қант диабетімен ауыратын жюне лактозаны көтере алмаушылывы бар адамдар үшін пайдалы бадам сүтінен балмұздақ алу технологиясы қарастырылады. Жұмыс барысында бадам сүтінің жсәе жаңа дайын өнімнің, физика-химиялық құрамы анықталды. Ұсынылzан жкаңа өнімде, рецептурада көп мөлшерде адам авзасына зиян келтіретін қант жоқ, дәмдік қасиеттерді беру үшін бай дәрумен-минералды құрамы, емдік қасиеттері және жсогары қоректік құндылывы бар финиктер қосылган. жемісі.

Негізгі сөздер: балмұздақ, бадам, органолептиткалық бақылау, рецептура, құрма 